\title{
Politics, Utopia and Disillusionment in NoViolet Bulawayo's We Need New Names (2013)
}

\author{
Babacar Diakhate \\ Laboratoire d'Études africaines et postcoloniales, Université Cheikh Anta Diop, Dakar, Sénégal \\ diakhatebabacar83@hotmail.fr
}

\begin{abstract}
This article brings to light political disillusionment in Zimbabwe under the presidency of Robert Mugabe. In We Need New Names (2013) NoViolet Bulawayo has explored how political disillusionment has triggered off the search for utopia in relation to migration. This paper portrays Darling, a victim of Mugabe's Operation Murambatsiva, has journeyed to America so as to find other opportunities. It also shows that in fleeing poverty in Zimbabwe to search for a better life in America, disillusionment is unavoidable because utopia is associated with disillusionment.
\end{abstract}

Keywords: disillusionment; Utopia; emigration; poverty; Money.

\section{Introduction}

In July 2005, Robert Mugabe proceeded to a national operation called Operation Murambatsiva or 'restoring order', which consisted in demolishing the derelict houses inhabited by the lower classes, pretexting to fight poverty. Instead of finding other governmental policies and measures to improve the lives of Zimbabweans, the operation had only brought about disaster. As Fitzpatrick puts:

In July 2005 around 650,000to 700,000 people had lost either the basis of their livelihood or their homes, or both. Mugabe's plan to "restore order" was to bulldoze communities with no warning and to push those to live in rural areas of Zimbabwe (Fitzpatrick: 2014, 10).

Therefore, in her fiction We Need New Names (2013), No violet Bulawayo has shown, how Mugabe' operation has drastically failed. Firstly, this article aims to show the circumstances or 'film' of the demolishing houses process, causing the displacement of the victims to foreign lands. Secondly, it also displays the 'utopian thought' of the victims before escaping to America. And finally, the paper elaborates the obstacles and disillusionment experienced by immigrants in foreign land.

\section{The Ironical Representation of Zimbabwe and Political Disillusionment}

In the seventies Zimbabwean people wrenched back their independence from the English administration. Robert Mugabe led successfully the struggle in order to take back their lands from the white possession. Therefore, in 1980 Zimbabwe became politically, socially and economically independent under the leadership of Mugabe. This political transition is what NoViolet Bulawayo tries to demonstrate in her fiction We Need New Names (2013) as she puts: Know this you bloody colonists, from now on the black man is done listening, you hear? This is black man country and the black man is in charge now. Africa for Africans (Bulawayo: 2013, 120).

However, the attainment of independence has not brought about social, political and economic improvement in the lives of Zimbabwean people. Indeed, social injustice is what characterizes the post-independence political leadership. Bulawayo portrays the betrayal of the masses by Mugabe during the last three decades of his leadership. This betrayal is displayed by the way in which the houses of the poorest populations are demolished by the 
paramilitary police with their Bulldozers. Since all the people of Zimbabwe have contributed to the liberation of their nation from the white hands, Bulawayo castigates this political disillusionment. She asserts: We fought for this fucking Lizwemoni, we put them in power, and today they turn on us like a snake mpthu(Bulawayo:2013, 69). Bulawayo depicts to what extent this political disillusionment overwhelms the minds of the victims. They cannot imagine such pitiless acts not from the whites who came to steal their lands and make them "paupers" but rather from their black leaders whom they expected to bring changes. She puts: It is ironic that, in the colonial era, it was the whites who drove them from their lands and put them in the reserves, yet the government does the same to them in the postcolonial era (Bulawayo: 2013, 75).

This has engendered the bitter discussion between two victims by comparing the white colonist political system and the African post-independence political system. While the first victim accuses the white colonialists of stealing the lands of their ancestors and make them "paupers" the second defends the idea that African post independent political leaders are just perpetuating the same political system, even worse.

She confirms: What, but aren't you a pauper now? Aren't these black people evil for bulldozing your home and leaving you with nothing now? (Bulawayo: 2013,75).The demolishing of houses has caused the depression of Nomviyo whose unique son was killed during the bulldozers breaking down houses. In turning back straight from town, she collapses because she notices that her house has just been broken down while her son, Freedom, is inside. The author describes the situation:

She is just returning from town. She sees all the broken houses and throws all the groceries and bags down, screaming, My son! My son! What happened? I left my Freedom sleeping in there! And they are helping her dig through the broken slaps and then Makubongwe we appear carrying Freedom, and his small body is so limp and covered in dust you think it's just a thing and not a baby( Bulawayo: 2013,69).

Bulawayo does an ironical representation and characterization of Mugabe's strong will to get rid of poverty by dissimulating the derelict houses. His governmental program of Operation Murambatsiva ('Restore Order') consists in demolishing houses without taking into account the masses. The derelict houses symbolize the level of poverty prevailing in the country. Instead of using adequate responses to alleviate the social living conditions of his citizens, Mugabe resorts to violent forces and solutions to fight poverty. Bulawayo depicts the methods adopted to restore order in the 'informal sector'. According to Bulawayo, this situation is nothing but Mugabe's bad political ruling system epitomized by corruption, Nepotism, embezzlement of public funds to the detriment of the masses. Bulawayo uses morality to 'preach' the government as she puts:

They should not have done this to us, no, they shouldn't have. Solilwelilizwe leli, we fought to liberate this country. Wasn't it like this before independence? Do you remember how the whites drove us from our land and put us in those wretched reserves? I was there, you were there, wasn't it just like this? Better a white thief do that to you than your OWN BLACK BROTHER. Better a wretched white thief.

Like Nomviyo, Darling as a teenager has also experienced this nightmare when the bulldozers appear in her dreams as ghosts and prevent her from sleeping. This past trauma may have left sequels in her for the rest of her life. Desiree Fitzpatrick in his article entitled "From Paradise to Destryedmichigen: An analysis of the Function of Names in We Need New Names" (2013) 
has examined the works of Deborah Potts to show the number of victims of Mugabe's "Restoring order" Programme. It is estimated that "in July 2005 that around 650,000 to 700,000 people had lost either the basis of their livelihood or their homes, or both (Fitzpatrick: 2014, 10).

Furthermore, the betrayal and political disillusionment of the masses by the Mugabe's government are not only confined in demolishing the houses of the lower class. Remarkably, there is the incapacity of the government to give the populations to eat to their full and to pay the salaries of civil servants. This hunger prevailing in the community is manifested when citizens are supposed to vote. Bulawayo shows: Somebody's stomach makes a loud sound and I remember I am hungry. We are all hungry but right now we do not care(Bulawayo: 2014, 70à74).This spontaneous hunger on the day of vote reminds citizens of starvation, which motivates the need to change the political system.

The government's incapacity to pay the civil servants is illustrated by the doctors who go on strike. The absence of doctors in the public hospitals has brought about the great number of traditional healers to compete with public health equipment. This traditional medicine has become the destination of many poor people who do not have access to hospitals. Bulawayo asserts: Prophet Revelation Mborro heals father and asks two virgin goats and five hundred U.S Dollars and because there are no Doctors or nurses at the hospital. They are always on strike (Bulawayo: 2013, 101). The author also describes the situation of young students who drop out schools because of the missing teachers who abandon their post for more lucrative opportunities. She admits: I do not go school anymore because all teachers left to teach over to in South Africa and Botswana and them, where there is better money... (Bulawayo: 2013, 30).

As a result, Bulawayo uses "Paradise" to ironize Zimbabwe and praises Budapest the real place to be, America. In "Paradise" everything is associated with 'kaka' therefore it is not appropriate for real people. Darling transcends hardship and poverty represented here by "Paradise" to live in Budapest. Darling puts: If $i$ lived in Budapest, I would wash my body and comb my hair nicely to show I was a real person living in a real place (Bulawayo:2013, 8).

Consequently, in We Need New Names (2013), Bulawayo has shown how political disillusionment and despair can lead the hopeless populations to escape to western countries in order to make their dreams come true. The hardship of life in "Paradise" because of betrayal and disappointment constitutes the ills that motivate the departure of Darling and all her friends for different destinations. Indeed, Darling has journeyed to America, Godknows flies to Dubai, Bastard goes to South Africa and Sbho joins the theater group and is travelling around the world to perform. Despite their young ages they undertake journeys to other unknown countries to escape poverty in "Paradise". Darling confesses: Then something shifts inside me and I start to feel disappointed, and then angry at our leaders for making it all happen, for ruining everything (Bulawayo: 2013, 287).

\section{Utopia and the Escape to America}

The quest for survival, a better life and material possession plunge Darling, Godknows, Sbho and Chipo into an utopian consciousness as Gift Mavezere puts: the journey to utopia with the negation of one's country as preparation or justification to leave their country (Bulawayo: 2013, 20). Gift's quotation is echoed by Ashcroft who asserts that Utopian thought keeps alive the likelihood of a world qualitatively unique from this one and takes the type of an unshakable refutation of all that is (Ashcroft: 2012,2). Langdridge further defines 
utopia saying: utopia is an unrealizable dream and escape which is not and cannot be achieved (Langdridge: 2006, 641); Darling dreams of leaving for America where she hopes that life will be better. She thinks that once she arrives in America, she will have access to a job and buy her own car. Her utopian consciousness is motivated when she comes across beautiful cars and promises to buy a "Lamborguini reventou" (Bulawayo: 2013, 111). Bastard, another Darling's dreadful friend also manifests his utopia when he arrives in Budapest, America. As he dreams: I'll make a lot of money and come back and make a house in this very Budapest. Or even better many houses: One in Budapest, one in Los Angeles, one in Paris. Wherever I feel like (Bulawayo: 2014, 15). All the children such as Darling, Bastard, Chipo and Sbho manifest their will to leave "Paradise" and undertake journeys in order to transcend, poverty, political disillusionment and social injustice.

This 'utopian consciousness' is also a central theme in Chika Unigwe's On Black Sisters Street( 2009), in which the author uses Sisi to display her strong commitment to change not only her own life but also to take over from her parents who just retired. Like Darling, Sisi is also a victim of a bad post-independence political system. Unigwe has castigated the incapacity of Nigerian political leaders to bring adequate responses to the socio-economic problems of their masses, which has impelled Sisi and her friends like Alice, Jake and Ama to leave for Belgium in quest of a better life. In this same vein, Sefi Atta has explored the relationships between the African political leaders and their populations. Indeed, in News from Home (2004) and Swallow (2010), Atta depicts how young Africans take the risk by challenging the Sahara desert in order to escape poverty. If there are some African candidates for immigration who challenge the Sahara desert by walking for months to reach Morocco, others prefer cars to their feet. This use of cars in the Sahara desert is well illustrated by Bulawayo in We Need New Names (2013). She describes:

Look at the children of land leaving in droves, leaving their own land with bleeding wounds on their bodies and shock on their faces and blood in their hearts and hunger in their stomach and grief in their footsteps. Leaving their mothers and fathers and children behind...Leaving the bones of their ancestors in the Earth, leaving everything that makes them who and what they are, leaving because it's no longer possible to stay(Bulawayo: 2013, 148).

In this quotation Bulawayo expresses her sorrow, sadness and regrets when she portrays the conditions in which young Africans are leaving their places of birth, where they have grown up. They turn their backs to their parents, their tradition and culture for unknown places just to flee betrayal, disillusionment, poverty and hypocrisy.

However, will their lives change?. Yet, it must be admitted that anyway their lives will change either positively or negatively. The fact of fleeing to America or other western countries does not certainly mean upward mobility. In this regard, Bastard has warned Darling by asking: What if you get there and find it's a "kaka place" and get stuck can't come back? (Bulawayo:2013, 16).

\section{Un/Achievements and Obstacles}

Before leaving their respective homes, the candidates for immigration thought that their lives in Europe or America would change. But in reality, the countries of destinations are not what they imagined. Bulawayo has successfully portrayed that disillusionment and betrayal are not the privilege of African countries. In We Need New Names (2013), the author tries to 
deconstruct the myth and the complexity that African boys have for the West. Like Atta, Unigwe and Adichie, Bulawayo also wants her readers to demystify the foreign land mostly taken by Africans as a "Golden place". Even though America or other European countries can obviously offer many jobs opportunities to immigrants, these opportunities go hand in hand with many pitfalls and dangers. The first obstacles that Darling is confronted with in America are integration, adaptation and racism. As Bulawayo shows:

When I first arrived at Washington Academy I just wanted to die. The other

kids teased me about my name, my accent, my hair, and the way I talked or said things, the way I dressed, the way I laughed ( Bulawayo: 2013, 167).

Additionally, Bulawayo's description of America's hostile weather is very important. She uses the snow in the text to epitomize how cold it is in America. This may be a huge obstacle to African immigrants to make their businesses successful. Therefore, Darling concludes that America is not her home. She owns up: It's the cold to stop life, to cut you open and blaze your bones. Nobody told me of this cold when I was coming here (Bulawayo: 2013, 156).

The problem of legal or illegal status of immigrants must also be explored. Most African immigrants settle in foreign lands without their legal resident papers, which have some repercussions in their daily activities. Since the advent of terrorism and extremism, many foreign countries have proceeded to a "chosen immigration" for security measures. This results in pushing some clandestine immigrants to get married with white people. Bulawayo has dealt with this phenomenon by showing how Dumi, a young African immigrant has managed to get married with a white woman. Bulawayo portrays Dumi: Dumi is tall and looks like he goes to the gym; he is not very handsome but he is better looking than uncle Kojo. I wish he didn't have his dread locks, though, they don't suit them (Bulawayo: 2013, 181).Therefore, Dumi gets married with a fat-ugly white woman just to get his resident papers. Most of the time, those young boys who are the targets of the white trashes are strong enough, sometimes with dreadlocks. It is during the wedding ceremony that some guests gossip in the toilet. She puts:

All I'll say it that he is a brave man. I mean if it's not bravery, then I don't

kwon what it is. Stupidity? Ah what a waste, and such a fine-ass brother too.

But the things people will do for these papers, my sister, I tell you (Bulawayo: 2013, 181).

For fear of coming back home empty-handed and be labeled a good-for-nothing son or daughter, clandestine immigrants get engaged in arranged marriages.

Bulawayo demonstrates that Zimbabwe ironized like a "KaKa place" is not home in the same manner as America is not home either. Darling and Bastard are in difficulty to meet their expectations. The fact of idealizing America as a "golden place" in the social media or on $\mathrm{TV}$ impels Darling's relatives to send her requests for financial supports. In order not to disappoint her extended family requests, immigrants worked themselves mad as Bulawayo demonstrates:

They had long ceased to be providers for us, we were now their parents. Our extended families sent requests and we worked, worked like donkeys, worked like slaves, worked like madmen. When we hesitate, they said, you are in America where everybody has money, we see it all on Tv, please don't deny us (Bulawayo: 2013, 247).

The problem of many immigrants is that they are not honest with themselves first before being so with their extended families they have left behind. Instead of telling them the reality 
in foreign lands, they choose the most beautiful places to take pictures to send them home. Darling puts:

We went to places and took pictures and sent them so they could see us in America. We took pictures outside the white house, we took pictures against the Lady Liberty as if she were our grandmother, we took pictures at the Niagara Fall, at the times Square, we took pictures with dolphins in Florida...we went everywhere and took picture and sent them home showing off a country that would never be ours (Bulawayo: 2013, 245).

These pictures taken in specific places may be incentive factors to attract other young Africans to undertake travels in order to be in America by all means necessary. But in reality there are two Americas: the fake one that Darling and her friends idealize through the social media and the real one in which Aunt Fostalina lives. The fact that Fostalina's handles two jobs shows the efforts made by immigrants to make hands meet.

\section{Conclusion}

Bulawayo has hopefully succeeded in showing the kinds of relationships that exist between some African presidents and their populations. At the beginning, the relationships are based on confidence or 'social contract'. However, this relationship, formerly based on "confidence", turns out to be based on disappointment and betrayal. This in what No violet Bulawayo, a young Zimbabwean female novelist, has tried to depict in We Need New Names (2013). Indeed, in her fiction the author accuses some African presidents, like Robert Mugabe, of being responsible for the phenomenon of young Africans who leave their countries for America to hope for a better life. But this African utopia may turn out to be disillusionment and betrayal.

\section{References}

Adichie, Chimamanda Ngozi (2004) Purple Hibiscus, Anchor.

Ashcroft, B.,Griffiths, G., Tiffin, G.( 2005) The postcolonial studies reader Routlegde: London and New York.

Atta, Sefi (2004) News From Home. Interlink Book.

........... (2010) Swallow. Interlink Book.

Bulawayo, No violet (2013).We Need New Names. New York: Hachette Book Group.

Desiree R. Fitzpatrick ( 2015) "From Paradise to Destroyedmichygen: An Analysis of the Function of Names in We Need New Names by No violet Bulawayo" Undergraduate Honors Thesis.874.https//scholar.colorado.edu Honors Thesis.874.

Langdridge, D. (2006) Ideology and Utopia: Social Psychology and Social Imaginary of PaulRicoeur.Theorypsychology16(641).pp641-659.

Available at: http://tap.sagepup.com/16/5/641.

Maverezee, Gift (2014) “The Search for Utopia in Noviolet Bulawayo's We Need New Names", Midlands State University.

Potts, Deborah.(2006)" Restoring Order"? Operation Murambatsiva and the Urban Crisis in Zimbabwe". Journal of Southern African Studies 32.2 (2006): 273-291. Historical Abstract with full text. Web.9Oct .2014.

Spivak, G.C. (2012) Gender in the Global Utopia. From translation Research Projects 4.eds. Anthony Pym and David Orrego-Carmona, Tarragona: Intercultural Studies Group. pp. 15

23 Available at: http:/.isg.urv.es/ publications/trp-4-2012/index.htm.

Unigwe, Chika (2009) Black Sisters Street. Random House: New York. 